NBER WORKING PAPER SERIES

\title{
INTERNATIONAL EVIDENCE ON TRADABLES \\ AND NONTRADABLE INFLATION
}

José De Gregorio

Alberto Giovannini

Holger C. Wolf

Working Paper No. 4438

\section{NATIONAL BUREAU OF ECONOMIC RESEARCH 1050 Massachusetts Avenue \\ Cambridge, MA 02138 \\ August 1993}

We are grateful to Roger de Ménil, Jeffrey Frankel, Robert Gordon, Richard Marston, Jorge Roldós, Linda Tesar, and participants at the International Seminar on Macroeconomics, and the NBER Summer Institute for valuable discussions and comments. We are also grateful to Reuven Glick, Xavier Sala-i-Martin, and Linda Tesar for helping us with the data. This paper is part of NBER's research program in International Finance and Macroeconomics. Any opinions expressed are those of the authors and not those of the National Bureau of Economic Research. 


\section{INTERNATIONAL EVIDENCE ON TRADABLES AND NONTRADABLES INFLATION}

\section{ABSTRACT}

Using 1970-1985 sectoral data for the OECD we find that inflation in nontradable goods is higher than in tradables. We identify a demand shift towards nontradables and faster growth of total factor productivity in the tradable goods sector as the prime causes of higher nontradables inflation. In addition, disinflation attempts and the exchange rate regime appear to have had significant influence on the relative inflation rate.

José De Gregorio

International Monetary Fund

700 19th Street, N.W.

Washington, DC 20431

Holger C. Wolf

Management Education Center

New York University

44 W 44th Street, Suite 7-78

New York, NY 10012-1126

and NBER

\author{
Alberto Giovannini \\ Graduate School of Business \\ Columbia University \\ and CEPR and NBER
}




\section{Introduction}

The disinflation experiences of the 1970s and 1980s, both within the group of OECD countries and outside it, have highlighted the role of international markets. Inflation appears to behave differently across sectors. Indeed, exchange-rate based stabilizations have been characterized by a higher rate of inflation in sectors sheltered from international competition. ${ }^{1}$ A difference in the behavior of inflation across sectors are also the definining feature of fluctuations in the real exchange rate (the relative price of nontradable goods ${ }^{2}$ ) in two-sector models of small open economies. ${ }^{3}$ Hence, discussions of exchange-rate misalignment have to focus on sectoral inflation.

In this paper we take a closer look at the determinants of differentials in sectoral inflation rates. We examine the time series and cross-sectional behavior of the relative price of nontradables in terms of tradables in a sample of fourteen OECD countries during the period 1970-85. We begin with the traditionally dominant supply side explanations, resting on the assumption of faster productivity growth in the tradables sector [Balassa (1964) and Samuelson (1964)]. ${ }^{4}$ The supply side approach yields a negative correlation between relative prices and relative production across sectors. In contrast, we find that in most OECD countries the increase in the relative price of nontradable goods has been accompanied by an increase in the share of output produced in the nontradable goods sector. We hence consider demand side shifts as additional determinants of relative price movements. Finally, we compare the evidence for the quasi-fixed exchange rate regime in the core EMS and the managed flexible exchange rate system in non-core European and non-European economies to determine whether the exchange rate regime played a role in addition to the demand and supply side factors.

\footnotetext{
${ }^{1}$ See, for example Kravis, Heston and Summers (1983), Summers and Heston (1991) De Gregario, Giovannini and Krueger (1993), and Micossi and Milesi-Ferretti (1993).

${ }^{2}$ For specificity, we will throughout the paper use the expression "relative price of nontradables". Nevertheless, it is useful to bear in mind that an increase in this relative price corresponds to a real appreciation.

${ }^{3}$ Developed originally by Salter (1959) and Swan (1960), and extended to incorporate intertemporal effects by Dombusch (1983), Edwards (1989), Frenkel and Razin (1992) and Rogoft (1992), among others.

'Kravis and Lipsey (1983) and Bhagwati (1984) presents an altemative supply-side view based on factor endowment differentials. The fairly narrow distribution of relative factor endowments across OECD economies [Wolf (1992)] renders this appraach more relevant for discussion of relative price movements between LDCs and DCs than for the dat asets underlying our analysis.
} 
The paper is divided into seven sections. We begin in section 2 by discussing the basic theoretical framework underlying our analysis. In -şections 3 and 4 we describe the data and propose a measure of tradability underlying our later empirical work. In section 5 we discuss the time series and cross sectional properties of relative prices and their determinants. Section 6 reports regression results aimed at disentangling the supply, demand and macroeconomic determinants of the relative price of nontradable goods. Section 7 concludes.

\section{A Conceptual Framework}

Balassa (1964) and Samuelson (1964) formalized - see also Harrod (1939), chapter IV, for an earlier discussion of this idea-what has since become the benchmark model of real exchange rate determination: faster productivity growth in the tradable than in the nontradable goods sector leads, via wage equalization, to a decline in the relative price of tradables.

To illustrate their proposition, consider the following production functions for the two sectors:

$$
Y_{T}=\theta_{T} L_{T}^{\alpha_{T}} K_{T}^{1-\alpha_{T}}
$$

and

$$
Y_{N}=\theta_{N} L_{N}^{\alpha_{N}} K_{N}^{1-\alpha_{N}}
$$

where the subscripts $T$ and $N$ denote tradable and nontradable goods, $Y$ denotes output, $L$ labor inputs, and $K$ capital. Under perfect competition prices in each sector are thus given by:

$$
P_{T}=\frac{1}{\theta_{T}} W^{\alpha_{T}} R^{1-\alpha_{T}} \alpha_{T}^{-\alpha_{T}}\left(1-\alpha_{T}\right)^{-\left(1-\alpha_{T}\right)}
$$

and

$$
P_{N}=\frac{1}{\theta_{N}} W^{\alpha_{N}} R^{1-\alpha_{N}} \alpha_{N}{ }^{-\alpha_{N}}\left(1-\alpha_{N}\right)^{-\left(1-\alpha_{N}\right)}
$$

where $W$ is the unit cost of labor and $R$ the rate of return on capital. Consider the case of a small open economy with perfect capital mobility, and express all prices in 
terms of the of tradable goods ( $P_{T}$ is the numeraire). Perfect capital mobility and law of one price in the tradable goods sector insures that the rate of return in tradables $R$ is equal to its world value. Defining $P$ as the relative price of nontradable goods, log-differentiating the expressions for prices, and then solving for the difference, it can be shown that:

$$
\hat{P}=\hat{\theta}_{T}-\hat{\theta}_{N}+\left(\alpha_{N}-\alpha_{T}\right) \hat{W}
$$

where the - denotes the rate of change.

Given $R$, equation (3) uniquely determines wages. Given both $W$ and $R$, equation (4) then uniquely determines the price of nontradables. Hence, as Rogoff (1992) emphasizes, under the joint assumption of a small open economy and perfect capital mobility the relative price of nontradable goods is determined exclusively by technological conditions and is independent of demand conditions.

Log-differentiating equation (3) and substituting into expression (5) yields an expression for the change in the relative price of nontradable goods: ${ }^{5}$

$$
\hat{P}=\frac{\alpha_{N}}{\alpha_{T}} \hat{\theta}_{T}-\hat{\theta}_{N}
$$

The intuition for the positive link between faster productivity growth in the tradable goods sector and the relative price of nontradable goods is straightforward: Imagine there is an increase in tradable goods productivity $\left(\theta_{T}\right)$ while nontradable goods productivity $\theta_{N}$ remains constant. Given the world real interest rate $R$ and given the price of tradables $P_{T}$, the productivity increase is matched by a real wage increase that keeps the marginal cost of tradables constant but increases the marginal cost, and hence the price, of nontradables. In contrast, an increase in $\theta_{N}$ with $0_{T}$ constant does not affect wages (determined in the tradable goods sector) and hence leads to a fall in the relative price of nontradables.

While demand shifts have no effects on the relative price of nontradable goods, they do alter the composition of output. To analyze the demand side of the economy, we consider the case of a representative consumer maximizing the present discounted value of

${ }^{5}$ Rogoff (1992) obtains the same equation from the factor market equilibrium conditions. See also Obstfeld (1993) 


$$
u\left(C_{N}, C_{T}\right)=C_{N}^{\phi}\left(C_{T}-\bar{C}\right)^{i-\phi}
$$

where $C_{N}$ and $C_{T}$ denote the consumption of nontradable and tradable goods, respectively. The parameter $\bar{C}$ represents the subsistence level of consumption of tradable goods, yielding a less than unitary income elasticity of the demand for tradable goods. For simplicity, the consumer is assumed to maximize utility on a period-by-period basis, subject to the budget constraint (expressed in terms of tradable goods): ${ }^{6}$

$$
I=C_{T}+P C_{N}+P G
$$

where $I$ is total income, and $\mathrm{G}$ is total government expenditure, falling entirely on nontradable goods and financed through lump sum taxation.

The corresponding demand functions are given by:

$$
C_{T}=\phi \bar{C}+(1-\phi)(I-P G)
$$

and

$$
C_{N}=\frac{\phi}{P}[I-P G-\bar{C}]
$$

If government expenditure is a constant fraction of total income, $P G=g I$, the total demand (public and private) for tradable and nontradable goods equals:

$$
C_{T}=(1-\phi)(1-g) I+\phi \bar{C}
$$

and

$$
C_{N}+G=[\phi+(1-\phi) g] \frac{I}{P}-\frac{\phi \bar{C}}{P}
$$

Hence for $\bar{C}>0$ the income elasticity of demand for tradables falls short of unity while that for nontradables exceeds unity, thus an increase in income will result in an increase in the consumption share of non-tradables. ${ }^{7}$

\footnotetext{
${ }^{6}$ The assumption rules out the use of the current account to smooth consumption, and thus ignores the different response of the economy to transitory and permanent shocks. For an intertemporal analysis of the current account and its empirical implications in a similar framework to the one of this paper see Stockman and Tesar (1990) and Glick and Rogoff (1993).

${ }^{7}$ See Bergatrand (1991). Relative demands may also be shifted by changes in the preference parameter $\phi$ [De Gregorio, Giovannini and Krueger (1993)]. In this case, increased demand for nontradables is again reflected by an increase in both the relative price and relative production of nontradable goods.
} 
Figure 1 illustrates the determination of relative prices and production as the intersection of the downward sloping relative demand for nontradable goods (the ratio of (12) and (11)) and the relative supply curve. Under the border case of perfect capital mobility the supply curve is horizontal (S1). While supply shocks affect both the equilibrium relative price $P$ and the relative production levels of tradable goods, demand shifts only affect the composition of output, but not relative prices. A nonzero slope of the relative supply curve-obtained by relaxing the extreme assumptions of perfect competition in goods and factors markets, law of one price for tradable goods, and perfect capital mobility-is thus a necessary condition for an effect of demand factors on relative prices (S2). ${ }^{8}$

It is useful to further separate shifts in relative demands by origin, distinguishing shifts in the preferences of the private sector from changes in the size of the public sector. Government expenditure has two effects on sectoral demands. It directly produces a range of nontradable commodities, ranging from healthcare to public safety. In addition, the financing of increased expenditures reduces disposable private income, a reduction which, given the income elasticities derived above, falls more heavily on the nontradable sector. As the overall decline in private sector spending on nontradables falls short of the increase in government spending on nontradables, the net effect of an increased public sector share is a shift in relative production and consumption towards the nontradable sector.

\section{Data}

The empirical work is based on the OECD international sectoral database, comprising fourteen countries ${ }^{9}$ and twenty sectors. ${ }^{10}$ The dataset includes output data in nominal

\footnotetext{
${ }^{8}$ The last option has been followed by Rogoff (1992) to find an explicit solution for changes in the real exchange rate in a model without capital mobility across sectors. See also Froot and Rogoff (1991b) for additional discussion.

${ }^{9}$ Australia (AUS), Belgium (BEL), Carada (CAN), Denmark (DNK), Finland (FIN), France (FRA), Germany (GER) , Italy (ITA), Japan (JPN), the Netherlands (NLD), Norway (NOR), Sweden (SWE), the United Kingdom (GBR) and the United States (USA).

${ }^{10}$ (1) Agriculture, (2) mining, (3) lood, beverages, tobacco, (4) textiles, (5) wood and wood products, (6) paper, printing, publishing, (7) chemicals, (8) non-metallic mineral products, (9) basic metal products, (10) machinery, equipment, (11) other manufactured products, (12) electricity, gas, water, (13) construction, (14) wholesale and ret ail trade, (15) restaurants, hotels, (16) transport, storage, communication, (17) finance, insurance, (18) real estate, (19) community, social and personal services and (20) government services.
} 
and real terms, permitting the construction of sectoral deflators, as well as detailed input data, permitting the derivation of sectoral total factor productivity levels.

We augment the OECD database by data on inflation, total government expenditures, and government expenditures on goods and services, taken respectively from the IMF International Financial Statistics, the IMF World Economic Outlook, and the United Nations Detailed National Account Statistics. We also use data on per capita GDP from the IMF World Economic Outlook. Our classification of sectors according to their level of tradability, discussed in the next section, is based on sectoral export data reported in the United Nations Trade Statistics for commodity exports, and in the IMF Balance of Payment Statistics for service exports.

\section{Tradability}

The theoretical literature on real exchange rates relies upon a neat division of commodities into "tradables" and "nontradables". Unfortunately few real world commodities fall easily into the nontradable category. Indeed, as Roy Harrod pointed out, virtually all commodities are tradable within some area, with the extent of the area determined by transportation cost. Notwithstanding, most economists would argue that certain commodities are in some sense inherently "less tradable" than others.

Shifting from theoretical to empirical work requires an operationalization of this prior. An obvious benchmark for tradability is the extent to which a particular good is actually traded. This benchmark implicitly underlies the shortcut adopted in most empirical work of labeling manufactures as "tradables" and services as "nontradables". While historically quite accurate, the often cited globalization of service markets casts doubts on the continued validity of this simple dichotomy for recent years. We make the implicit assumption explicit and base our classification on the ratio of total exports across all fourteen OECD economies to total production across all fourteen countries for each sector. We define a sector as "tradable" if more than 10 percent of total production within an area is exported. While the measure remains subjective in the selection of the particular threshold, it has the virtues of being based on the sample data and being easily subjectable to sensitivity checks.

Table 1 reports the ratio of total exports across the fourteen sample OECD coun- 
tries to the total value of production, both converted into US dollars, for all sectors. ${ }^{11}$ Among the four main sectors, manufacturing is seen to be most tradable under this definition, with exports amounting to 45.2 percent of production, followed by mining with 31.5 percent, agriculture with 23.6 percent and services with 4.3 percent. All sectors experience a sizeable increase in tradedness between 1970 and 1985, with a particularly pronounced increase in manufactures. The table provides little support for rapidly increasing service exports suggested in some informal accounts. Rather, overall the aggregate results support the standard practice of treating manufactures as tradables and services as nontradables goods.

Table 1: Tradedness

\begin{tabular}{||l|r|r|r|r||r|c||}
\hline \hline & 1970 & 1975 & 1980 & 1985 & Mean & T/NT \\
\hline \hline Agriculture & 17.3 & 24.3 & 28.1 & 24.7 & 23.6 & $\mathrm{~T}$ \\
\hline Mining & 29.6 & 36.9 & 27.9 & 31.4 & 31.5 & $\mathrm{~T}$ \\
\hline Manufacturing & 32.5 & 47.1 & 53.1 & 48.3 & 45.2 & \\
Metal Manufacturing & 42.6 & 64.5 & 69.2 & 63.4 & 59.9 & $\mathrm{~T}$ \\
Chemicals & 35.6 & 56.3 & 71.8 & 62.6 & 56.6 & $\mathrm{~T}$ \\
Basic Metals & 37.4 & 49.2 & 50.7 & 45.0 & 45.6 & $\mathrm{~T}$ \\
Textiles & 31.7 & 42.4 & 42.5 & 41.3 & 39.5 & $\mathrm{~T}$ \\
Other Manufactures & 28.1 & 30.6 & 39.8 & 35.8 & 33.6 & $\mathrm{~T}$ \\
Paper \& Products & 20.9 & 26.7 & 30.2 & 20.7 & 24.6 & $\mathrm{~T}$ \\
Food, Bev., Tobacco & 16.7 & 24.1 & 29.9 & 25.2 & 24.0 & $\mathrm{~T}$ \\
Non-Metallic Minerals & 10.3 & 12.7 & 16.4 & 15.4 & 13.7 & $\mathrm{~T}$ \\
\hline Services & 3.5 & 4.4 & 4.9 & 4.5 & 4.3 & \\
Transportation & 22.9 & 28.0 & 31.5 & 28.8 & 27.8 & $\mathrm{~T}$ \\
Other Services & 1.3 & 1.9 & 2.2 & 2.1 & 1.9 & $\mathrm{NT}$ \\
\hline
\end{tabular}

Export share in total production.

A look at more disaggregated data reveals substantial variation. Within manufacturing, export shares range from 60 percent for metal manufacturing to a low 14 percent for non-metal minerals. Within services, the low overall tradedness contrasts

\footnotetext{
${ }^{11}$ As lar as possible, missing observations were matched to avoid distortions.
} 
sharply with the 28 percent of transportation services production being exported in 1985. Indeed, the export share of the transport sector, the only subcomponent of services for which reliable export data are available, exceeds the export of three manufacturing subsectors, paper products, food and non-metal mineral products.

Our classification is reported in the last column of table 1 . With a 10 percent threshold, agriculture and mining are classified as tradables, as is all of manufacturing and transportation. The remaining services, accounting for about 50-60 percent of GDP, are treated as nontradables. ${ }^{12}$ The sizeable differences between sectoral shares provide our measure with some local robustness: cutting the threshold to 5 percent would have no effect, raising it to 20 percent would shift the quantitatively small non-metal mineral products from tradables to nontradables.

\section{Sectoral Inflation}

Based on the classification derived above, we aggregated the sectoral deflators to obtain aggregate price indices for tradable and nontradable commodities. The same aggregation was used to construct time series on sectoral total factor productivities. ${ }^{13}$ We begin our empirical discussion by examining the time series and cross sectional properties of these data.

Table 2 reports the mean and the standard deviation of the annual change in the relative price of nontradables to tradables. With the exception of Canada, the relative price of nontradables increased for all fourteen OECD economies over the 1970 to 1985 period, at an average of more than 1 percent per year. The results are quite dispersed, ranging from less than zero for Canada to the sustained 3.3 percent higher inflation rate for nontradables in Japan. Differentiating the core EMS economies (those who started within the narrow band in 1979: Belgium, Denmark, France, Germany, the Netherlands) from the remaining OECD economies however reveals a substantially lower dispersion of relative inflation rates within the core, suggesting a possible relationship between relative inflation rate dispersion and the exchange rate regime.

\footnotetext{
${ }^{12}$ Our classification coincides with that used by Stockman and Tesar (1991).

${ }^{13}$ Since the computations are sensitive to changes in the factor shares across time, we use the average factor share during 1970-85 for each sector and country.
} 
Table 2: Change in $P_{N} / P_{T}: 1970-85$

\begin{tabular}{|l|r|c||}
\hline OECD & Mean & St. Dev. \\
\hline \hline Australia & 1.70 & 3.67 \\
Belgium & 2.47 & 2.02 \\
Canada & -0.03 & 2.83 \\
Denmark & 0.81 & 2.12 \\
Finland & 1.05 & 2.67 \\
France & 1.97 & 1.63 \\
Germany & 1.34 & 1.75 \\
Italy & 1.73 & 3.25 \\
Japan & 3.35 & 2.42 \\
Netherlands & 1.45 & 3.73 \\
Norway & 1.37 & 4.52 \\
Sweden & 1.05 & 2.98 \\
United Kingdom & 1.37 & 5.04 \\
United States & 1.12 & 2.20 \\
\hline
\end{tabular}


Figure 2 plots the change in the share of nontradables against the average annual change in the relative price of nontradables. The figure reveals a negative correlation: the larger the increase in the relative share of nontradables, the smaller the average annual increase in the relative price of nontradables. The figures furthermore reveal that eight of the fourteen OECD economies experienced both an increase in the relative price of nontradables and an increase in the relative share of nontradables. Only Japan and Norway experienced an increase in the share of tradable goods above half of a percentage point. This positive comovement between relative price and relative output changes suggests that demand side factors played a significant role in the determination of relative output.

Table 3 reports the correlation of the tradables inflation rates across the OECD economies, expressed in common currency. Under relative purchasing power parity, the correlation would approach unity. In line with a sizeable previous literature, PPP in this simple sense is rejected for the overall sample. Looking separately at the EMS core however reveals a fairly close correspondence: the correlation of the German tradables inflation rate with France amounts to 0.91, with the Netherlands to 0.97, with Belgium to 0.91 and with Denmark to 0.93 . In contrast, the correlation with European non-EMS economies and non-European countries is significantly lower, with a zero correlation with the US and a negative correlation with Canada. The data thus suggest a fair degree of comovements of tradable prices within quasi-fixed exchange rate blocs, with fairly small correlations between countries linked by flexible exchange rates. ${ }^{14}$

Interestingly, both the same pattern and-more strikingly-almost the same numerical values are observed for the correlations of nontradable goods inflation rates (Table 4). Again, the average correlation between core countries, at 0.92 , substantially exceeds both the average correlation within non-core countries $(0.74)$ and the average correlation across the entire sample (0.53).

The close comovements of both tradable and nontradables prices across the core admits two explanations under the framework laid out above. First, productivity shocks to both the tradable and nontradable sectors could be more similar within the core compared to between core and non-core. Second, demand side shocks, such as

\footnotetext{
${ }^{14}$ This is consistent with the findings of Mussa (1986).
} 
fiscal shifts and income growth, could be more correlated within the core. Moving beyond the narrow confines of the model, the striking differences between the subgroups of economies operating under fixed and under flexible exchange rates suggests that the exchange rate system may have played an additional independent role.

Table 3: Tradable Goods Inflation: Correlations

\begin{tabular}{||l||r|r|r|r|r|r|r|r|r||r|r|r|r|r|}
\hline & AU & CA & JP & US & FI & IT & NO & SW & UK & BE & DE & FR & GE & NE \\
\hline \hline AUS & 1 & & & & & & & & & & & & & \\
CAN & .28 & 1 & & & & & & & & & & & & \\
JPN & .35 & .17 & 1 & & & & & & & & & & & \\
USA & .06 & .62 & .38 & 1 & & & & & & & & & & \\
FIN & .24 & -.01 & .37 & -.04 & 1 & & & & & & & & & \\
ITA & .26 & -.03 & .47 & .16 & .76 & 1 & & & & & & & & \\
NOR & .12 & -.09 & .14 & -.02 & .58 & .67 & 1 & & & & & & & \\
SWE & .39 & -.06 & .24 & -.14 & .85 & .71 & .81 & 1 & & & & & & \\
GBR & .57 & -.06 & .39 & .13 & .58 & .73 & .30 & .45 & 1 & & & & & \\
\hline \hline BEL & .30 & -.22 & .41 & -.14 & .78 & .77 & .82 & .89 & .57 & $\mathbf{1}$ & & & & \\
DNK & .17 & -.13 & .28 & .01 & .70 & .81 & .90 & .84 & .52 & .94 & 1 & & & \\
FRA & .25 & -.18 & .32 & -.09 & .79 & .87 & .89 & .90 & .55 & .94 & .95 & 1 & & \\
GER & .13 & -.25 & .28 & .00 & .70 & .74 & .88 & .77 & .56 & .91 & .93 & .91 & 1 & \\
NET & .06 & -.20 & .29 & .13 & .63 & .77 & .85 & .68 & .57 & .87 & .93 & .87 & .97 & 1 \\
\hline
\end{tabular}

Table 5 reports the summary of the correlations of demand and supply factors across several groups of countries for the entire 1971-1985 period. Among European countries we separate out the core EMS economies (Belgium, Denmark, France, Germany, Netherlands). We also report the average correlations for the subset of non-European countries and the total sample of 14 countries.

The data reveal a moderately positive correlation of both supply side and demand side shocks for the entire sample. Separating the European economies into core and non-core suggests a substantially higher correlation of demand and supply shifts within the core. A comparison of European and non-European economies reveals 
Table 4: Nontradable Inflation: Correlations

\begin{tabular}{||l|r|r|r|r|r|r|r|r|r||r|r|r|r|r|}
\hline & AU & CA & JP & US & FI & IT & NO & SW & UK & BE & DE & FR & GE & NE \\
\hline AUS & 1 & & & & & & & & & & & & & \\
CAN & .35 & 1 & & & & & & & & & & & & \\
JPN & .50 & .15 & 1 & & & & & & & & & & & \\
USA & .20 & .57 & .28 & 1 & & & & & & & & & & \\
FIN & .56 & .14 & .21 & -.05 & 1 & & & & & & & & & \\
ITA & .46 & .23 & .33 & .24 & .80 & 1 & & & & & & & & \\
NOR & .41 & .04 & .07 & .02 & .86 & .84 & 1 & & & & & & & \\
SWE & .59 & .13 & .11 & .02 & .85 & .80 & .93 & 1 & & & & & & \\
GBR & .58 & .15 & .42 & .02 & .65 & .72 & .49 & .49 & 1 & & & & & \\
\hline \hline BEL & .53 & .10 & .37 & .01 & .89 & .87 & .93 & .86 & .64 & 1 & & & & \\
DNK & .45 & .06 & .30 & .11 & .86 & .88 & .95 & .84 & .54 & .97 & $\mathbf{1}$ & & & \\
FRA & .47 & .08 & .28 & .04 & .88 & .91 & .95 & .91 & .53 & .95 & .96 & $\mathbf{1}$ & & \\
GER & .30 &. .06 & .25 & .09 & .79 & .81 & .90 & .71 & .52 & .91 & .96 & .89 & 1 & \\
NET & .36 & .07 & .23 & .15 & .83 & .90 & .89 & .72 & .68 & .91 & .94 & .88 & .96 & 1 \\
\hline
\end{tabular}

Table 5: Average Correlations

\begin{tabular}{|c|c|c|c|c|}
\hline \multirow[t]{3}{*}{ Variable } & \multicolumn{2}{|c|}{ European Countries } & \multirow[t]{3}{*}{ Non-Eur. } & \multirow[t]{3}{*}{ OECD } \\
\hline & Core EMS & Non-Core & & \\
\hline & Countries & Sample & & \\
\hline \multicolumn{5}{|l|}{$1971-85$} \\
\hline Tradable Goods Inflation & 0.92 & 0.64 & 0.31 & 0.45 \\
\hline Nontradable Goods Inflation & 0.93 & 0.74 & 0.34 & 0.53 \\
\hline Tradable Productivity Growth & 0.59 & 0.37 & 0.61 & 0.44 \\
\hline Nontradable Productivity Growth & 0.42 & 0.28 & 0.28 & 0.29 \\
\hline Income Growth & 0.65 & 0.34 & 0.60 & 0.46 \\
\hline Fiscal Expenditure Growth & 0.46 & 0.29 & 0.43 & 0.36 \\
\hline
\end{tabular}


a higher correlation of demand and supply shifts relative to inflation rates for the former, with reverse results for the non-European economies.

Table 6: Average Correlations in European Countries: Subperiods

\begin{tabular}{||l|c|c|c||}
\hline Variable & Core EMS & Non-Core & All \\
\hline \hline 1971-78 & & & \\
Tradable Goods Inflation & 0.87 & 0.69 & 0.75 \\
Nontradable Goods Inflation & 0.85 & 0.70 & 0.75 \\
Tradable Productivity Growth & 0.70 & 0.33 & 0.49 \\
Nontradable Productivity Growth & 0.55 & 0.25 & 0.43 \\
Income Growth & 0.77 & 0.20 & 0.45 \\
Fiscal Expenditure Growth & 0.60 & 0.28 & 0.41 \\
\hline \hline 1979-85 & & & \\
Tradable Goods Inflation & 0.90 & 0.86 & 0.87 \\
Nontradable Goods Inflation & 0.93 & 0.90 & 0.90 \\
Tradable Productivity Growth & 0.47 & 0.36 & 0.45 \\
Nontradable Productivity Growth & 0.14 & 0.29 & 0.19 \\
Income Growth & 0.40 & 0.52 & 0.50 \\
Fiscal Expenditure Growth & 0.32 & 0.29 & 0.35 \\
\hline
\end{tabular}

The results are suggestive of an additional determinant of inflation correlations in Europe. While the exchange rate regime provides an obvious candidate, the possibility of reverse causation must be taken into account: the higher correlations of sectoral inflation rates and their determinants within the core-EMS countries may precede the creation of the EMS and may indeed have been the reason leading these countries to join the EMS. To control for possible reverse causation we divide the sample period into pre-EMS (1971-78) and post-EMS (1979-1985). The results are shown in Table 6. While inflation correlations have increased uniformly across Europe, the correlations of demand and supply side factors have increased for the non-core but decreased for the core economies. The marked difference between core and non-core over the two subsamples is suggestive of an additional role of the exchange rate system in bringing about the higher correlation of inflation rates. 
To summarize, our initial exploration of the data has yielded a number of interesting results:

- The relative price of nontradables has increased almost uniformly across the fourteen OECD economies over the 1970 to 1985 period.

- Most countries experienced both an increase in the relative size of the nontradables sector and an increase in the relative price of nontradables. The change in relative size and in relative price of non-tradeables were negatively correlated.

- The correlation of inflation rates, productivity growth rates, income growth and fiscal growth rates has been substantially higher within the quasi-fixed exchange rate bloc of the EMS core compared to non-core countries. For the core economies, the correlation of demand and supply side shifts fall short of the inflation correlations. While the correlation of inflation rates has increased for all European countries in the period 1979-85 compared to the period 1971-78, the correlation of demand and supply side shocks over the same periods increased for the non-core but decreased for the core economies.

\section{Determinants of the Relative Price of Nontradables}

As a first pass at examining the Harrod-Balassa-Samuelson (HBS) hypothesis, figure 3 plots equation (6), the weighted relative productivity growth against the change in relative prices. Total factor productivity growth is seen to be higher in the tradable goods sector (corrected by factor shares) for all the sample countries, as suggested by the original HBS hypothesis. ${ }^{15}$ Furthermore, the figure reveals the positive correlation between the productivity growth differential and the increase in the relative price of nontradable goods suggested by HBS.

Taken in conjunction with the finding in figure 2 of a negative relationship between the relative change in the price of nontradables and the increase in the share of nontradables, a first glance at the data thus suggest a significant role of supply side factors. However, the simultaneous increase in both the relative price and the relative share of nontradables for a sizable subset of countries suggests that demand side

\footnotetext{
${ }^{15}$ This result is (empirically) not driven by the correction $\alpha_{N} / \alpha_{T}$, it holds when both shares are assumed to be the same.
} 
factors also matter. We next turn to econometric analysis to disentangle the relative contribution of the two effects. ${ }^{16}$ To distinguish the two effects, we add demand side factors to the right hand side of equation (6) and estimate the reduced form equation (13):

$$
P_{i, t}=\beta_{0 i}+\beta_{1} \theta_{i, t}+\beta_{2} g_{i, t}+\beta_{3} y_{i, t}+\beta_{4} \Delta \pi_{i, t}
$$

where $\theta$ corresponds to the difference of total factor productivity across sectors corrected by the labor shares (as in equation (6)), the subscripts $i$ and $t$ indicate country and time, $g$ is government expenditure over GDP (both in real terms), $y$ is the level of per capita income, and $\Delta \pi$ is the first difference of the rate of inflation.

The coefficient $\beta_{1}$ measures the impact of productivity growth as suggested by HBS with an expected positive sign. The next two variables ( $g$ and $y$ ) proxy demand shifts. While in general the coefficients depend on both supply and demand side factors, for the specific case of a flat supply curve $\beta_{2}$ and $\beta_{3}$ will be zero. Significant coefficients on income and fiscal growth are thus sufficient to rule out the flat supply curve assumption underlying the pure HBS model. With a positively sloped supply curve, both variables are expected to enter positively. Finally, relaxing the assumption of instantaneous price adjustment in the non-traded sector, we include the first difference of inflation to capture the possibility of transitory dynamics. If price adjustment in the nontradable sector is more sluggish, an attempt to bring about disinflation via exchange rate appreciation leads to a temporary decline in the relative price of nontradables and a temporary expansion of relative tradables production, leading to a predicted negative sign on $\beta_{\mathbf{4}}$. For example, De Gregorio, Giovannini and Krueger (1993) discuss the effects of unwarranted wage increases reflecting e.g. lacking credibility of macroeconomic policy(makers). With the law of one price holding in tradables, the wage pressure will be manifested solely in the nontradable sector, resulting in an increase in the relative price of nontradable goods and a reduction in the relative output of tradables.

Because of the high persistence of the explanatory variables as well as of the residuals in the level equation, all regressions were run in first differences using seemingly

\footnotetext{
${ }^{16}$ For related empirical evidence on determinants of the real exchange rate see Hsieh (1982), Marston (1987), Froot and Rogoff (1991a, b), Bergstrand (1991), De Gregorio, Giovannini and Krueger (1993), and Wolr (1993).
} 
unrelated regression with common coefficients across countries. The results are presented in table $7 .{ }^{17}$ Estimation by SUR in first differences eliminates the constant. ${ }^{18}$ All regressions but 3 and 4 use total government expenditure in GDP, with a sample average of 19.4 percent. Regression 3 excludes from government spending the subcategory "total purchases of goods and services," with a sample average of 5.2 percent, to obtain a closer approximation of spending on non-tradeables. The remaining government expenditure comprises mostly employment compensations, amounting to roughly three quarters of total government expenditure. Regression 4 uses, instead, only purchases of goods and services. The number of observations in regressions 3 and 4 declines because data are not available for Belgium and Italy.

The coefficients on total factor productivity differentials have the expected value in all the specifications and are statistically significant. The average coefficient estimate of 0.23 (in regressions 1-4) implies that a 3 percentage points faster productivity growth in the tradable goods sector results in a 0.7 percent increase in the relative price of nontradables. The coefficient on total factor productivity differentials increases somewhat when income growth or changes in government expenditure are omitted from the regressions (see 5-7). The highest point estimate is 0.38 .

The coefficient on total government expenditure over GDP (regressions 1-2, and 5-8) is always positive and significant, with point estimates ranging between 1.5 and 2.0 , suggesting that an increase of one percentage point in the share of government expenditure increases the relative price of nontradable goods by 1.5 to 2 percent. Regression 3, which uses employment compensations, shows no significant differences with 1 . However, regression 4 , which uses only the subcategory of purchases of goods and services, yields an insignificant coefficient, lending credence to the use of the compensation variable as a better measure of government nontradables spending.

\footnotetext{
${ }^{17}$ To test for robustness, all regression reported in this section and the evidence presented in the previous section were performed with two alternative classifications. The first one excluded electricity, gas and water, production of government services, and other services from the nontradable goods sector, and included transportation, storage and communication services as nont radable goods. The second altemative classification looked at a narrower set of sectors, by including only manufacturing as tradable goods; and wholesale and retail trade, restaurants, hotels, transport, storage, communication, finance, insurance, real estate, and community, social and personal services as nontradables. Overall, the results were robust to this changes of classification, indicating that our result are not stemming from some specific sector misclassified.

${ }^{18}$ To capture potential country specific effects, the regressions were also estimated with country specific intercepts, and the results did not change significantly.
} 
Table 7: Regression Results

\begin{tabular}{||c|r|r|r|r|c||}
\hline Regression No. & $\beta_{1}$ & $\beta_{2}$ & $\beta_{3}$ & $\beta_{4}$ & No. of Obs. \\
\hline 1 & 0.234 & 1.974 & 0.281 & & 210 \\
& $(0.018)$ & $(0.119)$ & $(0.030)$ & & \\
\hline 2 & 0.234 & 1.846 & 0.272 & -0.045 & 210 \\
& $(0.015)$ & $(0.104)$ & $(0.025)$ & $(0.010)$ & \\
\hline 3 & 0.208 & 2.015 & 0.292 & & 180 \\
& $(0.019)$ & $(0.119)$ & $(0.024)$ & & \\
\hline 4 & 0.246 & 0.428 & 0.169 & & 180 \\
& $(0.032)$ & $(0.291)$ & $(0.042)$ & & \\
\hline 5 & 0.375 & 1.496 & & & 210 \\
& $(0.015)$ & $(0.099)$ & & & \\
\hline 6 & 0.267 & & 0.092 & & 210 \\
& $(0.023)$ & & $(0.027)$ & & \\
\hline 7 & 0.328 & & & & 210 \\
& $(0.013)$ & & & & \\
\hline 8 & 0.235 & 1.936 & 0.296 & -0.037 & 210 \\
& $(0.017)$ & $(0.113)$ & $(0.027)$ & $(0.011)$ & \\
\hline
\end{tabular}

All regressions were estimated using SUR for the first differences of (13).

Regressions 3 and 4 uses a narrower measure of government expenditure (see text).

Regression 8 includes two dummy variables for the oil shocks (see text). 
The second demand variable, income growth, enters positively as expected, and in most cases significantly, with a coefficient in the order of 0.24 and 0.29 (except in regressions 4 and 6 , where the exclusion of the relevant component of government expenditure reduces the point estima te to 0.17 and 0.09 , respectively) suggesting that a five percent income growth would be matched by a 1 percent increase in the relative price of nontradables. Several authors have interpreted the positive correlation between the relative price of nontradables as an indication of the importance of productivity differentials [e.g., Kravis, Heston and Summers (1983)]. Implicitly, these authors thus associate income growth solely with supply rather than demand factors. The regressions however reveal an effect of income growth on the relative price of nontradable goods even after controlling for productivity differentials, justifying its interpretation as an indicator of demand.

Regressions 2 and 8 reveal some evidence for differential price adjustment speeds across sectors: in the sample, disinflation is associated with an increase in the relative price of nontradables, suggesting more flexible tradable goods prices in line with the discussion of section 2 . The finding is consistent with the real appreciation typically observed in the aftermath of exchange rate stabilizations. Interestingly, the effect appears to be common across exchange rate regimes: including a dummy variable interacting with the acceleration of inflation for core EMS economies versus non-EMS yielded an insignificant coefficient.

Finally, we examine the potential role of the two oil price shocks falling within our sample. By inducing a simultaneous decline in both income and the relative price of nontradables, an oil price increase potentially enhances the negative correlation illustrated earlier. Regressions 2 and 8 includes 2 dummy variables for the oil shocks, taking values of one in 1974-75 and in 1979-80 respectively. However, little evidence for a major role emerges: the dummies were marginally significant, and the parameter estimates remain almost unchanged. Including measures of the real price of oil likewise does not suggest that the two oil price shocks contributed significantly to the stylized facts presented above.

The results presented so far suggest a rather more important role for demand side movements than suggested by the previous literature. To some degree, our results may however depend on the use of relatively high frequency data, potentially concealing long run trends. While our results reject the notion of a short run flat supply curve, 
it may be more reasonable to think of perfect capital mobility as holding over the long run, and thus of the supply curve becoming flatter as the observation frequency declines. To allow for this possibility we estimate regression (13) using the average rate of growth of the variables during the period 1970-85:19

$$
\Delta P_{i}=0.741 \Delta \theta_{i}-0.002 \Delta g_{i}+0.032 \Delta y_{i}
$$

$R^{2}=0.31$, and $\mathrm{N}$ obs. $=14$.

The coefficient on total factor productivity differentials increases and becomes insignificantly different from unity. In contrast, the coefficients on the share of government expenditure and per capita income become insignificantly different from zero, indicating an increased importance of supply and a diminishing importance of demand factors in the long run.

In order to disentangle the relative importance of demand and supply factors in the rising trend of the relative price of nontradables, table 8 uses the estimated short (equation 1 in table 7) and long run (equation (14)) regression equations to decompose the average annual increase in the relative price of nontradables into the contribution made by the faster growth of total factor productivity in the tradable goods sector, the contribution made by increasing government expenditures and income, and a residual. ${ }^{20}$ While the high correlation the explanatory variables suggests some caution in interpreting the table, the results indicate that in the short run demand side factors, in particular income growth, rather than relative productivity growth differentials were the dominant determinant of relative price changes over the sample period. Government spending plays a fairly secondary role, reflecting the small overall change in the share of government spending during the sample period [see also De Gregorio, Giovannini and Krueger (1993)]. In the long run, as reflected in the coefficients of equation (14), most of the increase in the relative price of nontradables can be explained by the faster increase of total factor productivity in the tradable goods sector.

\footnotetext{
${ }^{19}$ Since we are interested in trend movements, we exclude the temporary effects from changes in inflation.

${ }^{20}$ Since we are interested in trend movements, we exclude the temporary eftects from changes in inflation. The percentage change in the relative price of nontradables is calculated as the log-difference. Table 2 employed the $15^{\text {th }}$ root, resulting in small differences between the average in the two tables.
} 
Table 8: Actual and Explained Changes in $P_{N} / P_{T}$. Full OECD Sample

\begin{tabular}{||c|c|c|c|c|c||}
\hline & Actual & $\begin{array}{c}\text { Productivity } \\
\text { Differential }\end{array}$ & $\begin{array}{c}\text { Government } \\
\text { Expenditure }\end{array}$ & $\begin{array}{c}\text { Income } \\
\text { Growth }\end{array}$ & Residual \\
\hline Short Run & 1.31 & 0.42 & 0.10 & 0.61 & 0.17 \\
Long Run & 1.31 & 1.00 & 0.00 & 0.07 & 0.00 \\
\hline
\end{tabular}

\section{Concluding Remarks}

The failure of high inflation countries in the OECD to converge towards their better performing partners has been often attributed to lacking credibility arising from the strategic interactions among unions, employers, and policymakers. The results of this paper suggest that more fundamental factors may also be to blame.

Examining sectoral data for 14 OECD countries we find that inflation over the 1970 to 1985 period has been driven predominantly by the nontradables sector. Examining the determinants of relative inflation rates we find empirical support for several effects. First, through its impact on the composition of demand, trend growth in income (and to a lesser extent government spending) has contributed to the increase in the relative price of nontradables. Second, higher trend growth of total factor productivity in tradables has operated in the same direction, suggesting that efforts to raise productivity growth in the nontradables sector, for example by stimulating increased competition, may provide a promising avenue towards disinflation. Third, we also find that the relative price of nontradables decrease as inflation accelerates, suggesting differential adjustment speeds across sectors.

The data reveal a substantially higher correlation between demand and supply shifts, and hence of relative price movements for the EMS-core countries. Moreover, sectoral inflation rates are substantially more correlated among the EMS core than are the demand and supply factors. These findings suggest a potential effect of the exchange rate regime on relative price movements. 


\section{References}

Balassa, B. (1964), "The Purchasing-Power-Parity Doctrine: A Reappraisal," Journal of Political Economy, 72 (December): 584-96.

Bergstrand, J. (1991), "Structural Determinants of the Real Exchange Rates and National Price Levels," American Economic Review, 81 (March): 325-334.

Bhagwati, J. (1984), "Why Are Services Cheaper in the Poor Countries?," Economic Journal, 94 (June): 279-286.

De Gregorio, J., A. Giovannini and T. Krueger (1993), "The Behavior of Nontradable Goods in Europe: Evidence and Interpretation," IMF Working Paper No. $\mathrm{WP} / 93 / 45$.

Dornbusch, R. (1983), "Real Interest Rates, Home Goods, and Optimal External Borrowing," Journal of Political Economy, 91 (February): 141-153.

Edwards, S. (1989), Real Exchange Rates, Devaluation, and Adjustment: Exchange Rate Policy in Developing Countries, Cambridge, Mass.: MIT Press.

Frenkel, J. and A. Razin (1992), Fiscal Policies and the World Economy, 2nd Edition, Cambridge: MIT Press.

Froot, K. and K. Rogoff (1991a), "The EMS, the EMU and the Transition to a Common Currency," NBER Macroeconomics Annual 1991, Vol 6: 269-317.

Froot, K. and K. Rogoff (1991b), "Government Spending and the Real Exchange Rate: The Empirical Evidence," mimeo, Harvard University (August).

Glick, R. and K. Rogoff (1993), "Global versus Country-Specific Shocks and the Current Account," mimeo, Federal Reserve Bank of San Francisco and Princeton University.

Harrod, R. (1939), International Economics, Cambridge, U.K.: Cambridge University Press.

Hsieh, D. (1982), "The Determination of the Real Exchange Rate: The Productivity 
Approach," Journal of International Economics, 12 (May): 355-362.

Kravis, I., A. Heston and R. Summers (1983), "The Share of Services in Economic Growth," in F. Adams and B. Hickman, eds., Global Econometrics: Essays in Honor of Lawrence R. Klein, Cambridge, Mass.: MIT Press.

Kravis, I. and R. Lipsey (1983), Towards an Explanation of national Price Levels, Princeton Studies in International Finance No. 52, Princeton University, International Finance Section.

Marston, R. (1987), "Real Exchange Rates and Productivity Growth in the United States and Japan"; in S. Arndt and D. Richardson (eds.) Real-Financial Linkages Among Open Economies, Cambridge, MIT Press.

Micossi, S. and G. Milesi-Ferretti (1993), "Real Exchange Rates and Non-Tradable Goods Prices in the EMS," mimeo, IMF.

Mussa, M. (1986), "Nominal Exchange Rate Regimes and the Behavior of Real Exchange Rates: Evidence and Implications," Carnegie Rochester Conference Series in Public Policy, 25: 117-214

Obstfeld, M. (1993), "Modeling Trending Real Exchange Rates," Center for International and Development Economics Research, University of California at Berkeley, Working Paper No. C93-011.

Rogoff, K. (1992), "Traded Goods Consumption Smoothing and the Random Walk Behavior of the Real Exchange Rate," NBER Working Paper No. 4119.

Salter, W. (1959), "Internal and External Balance: The Role of Price and Expenditure Effects," Economic Record, 35: 226-238.

Samuelson, P. (1964), "Theoretical Notes on Trade Problems," Review of Economic and Statistics, 46 (March): 145-154.

Stockman, A. and L. Tesar (1990), "Tastes and Technology in a Two-Country Model of the Business Cycle: Explaining International Comovements," NBER Working Paper No. 3566 .

Summers, R. and A. Heston (1991), "The Penn World Table (Mark V): An Extended 
Set of International Comparisons, 1950-1988," Quarterly Journal of Economics, 104 (May): 327-368.

Swan, T. (1960), "Economic Control in a Dependent Economy," Economic Record, 36: 51-66.

Wolf, H. (1992), “The Relative Factor Endowments Model of Trade Determination: A Premature Burial?," sl Estudios de Economia, forthcoming.

Wolf, H. (1993), "The Law of One Price, Transportation and Local Distribution Costs: A Cross-City Study," mimeo, New York University. 
Figure 1

Equilibrium Relative Price and Production of Nontradable Goods

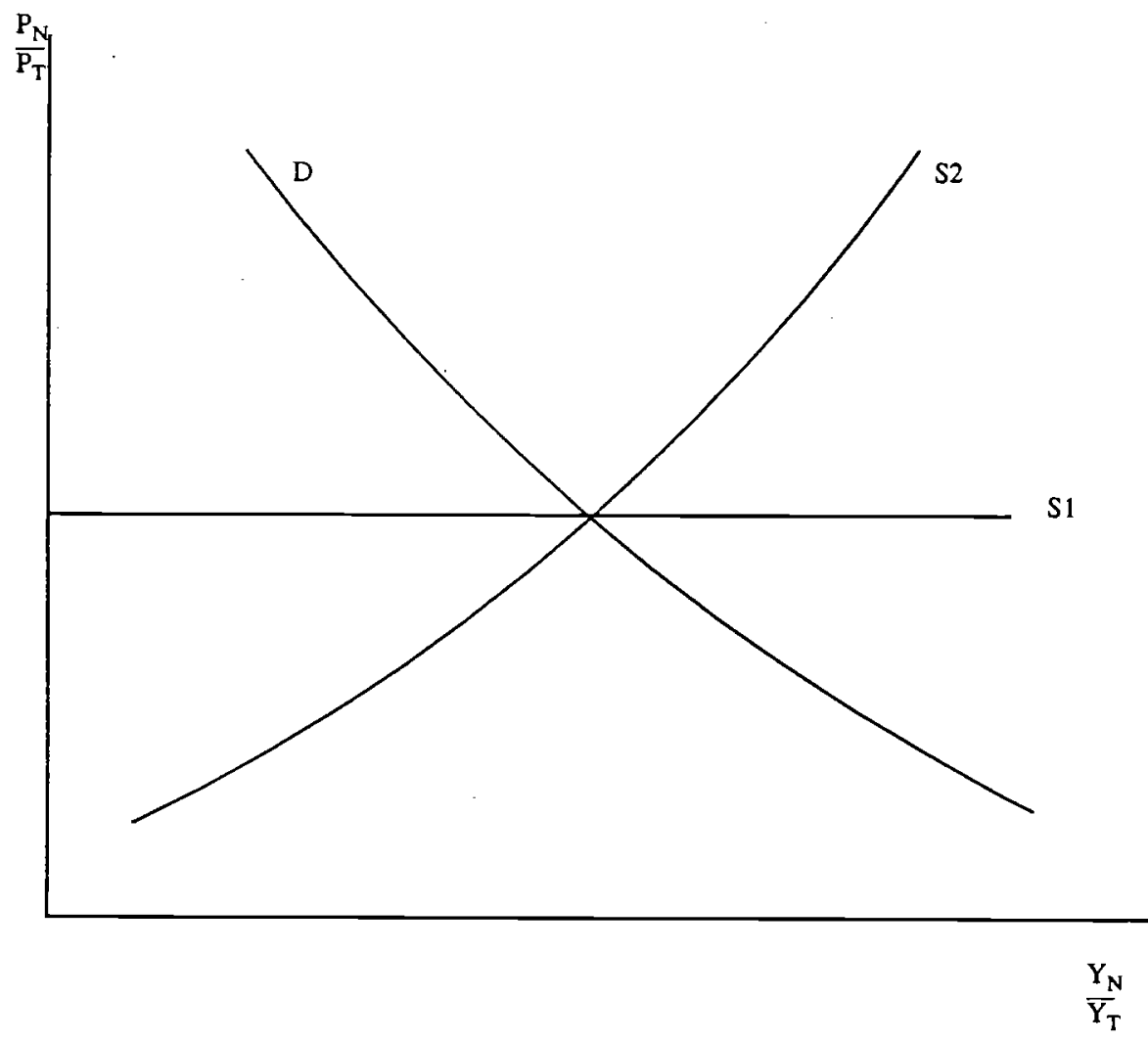


Figure 2

Changes in Share and Relative Price of Nontradables

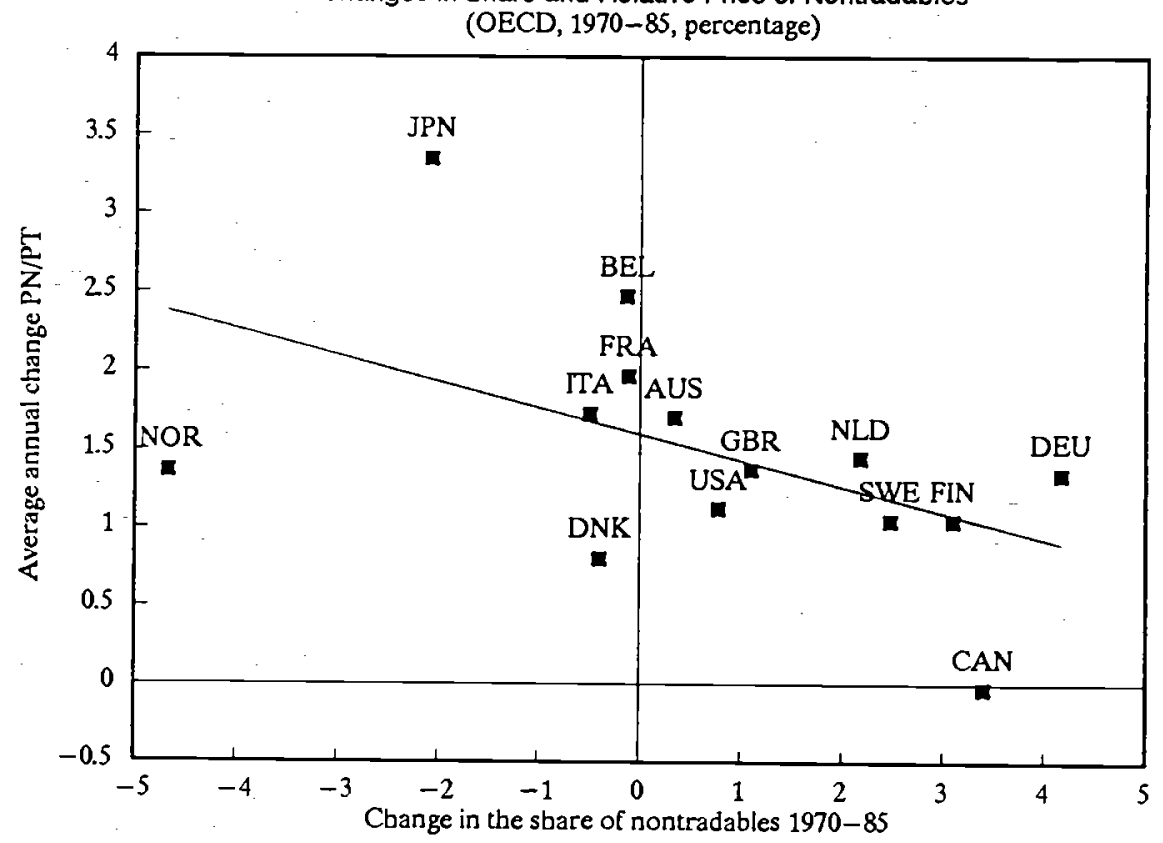


Figure 3

Differential factor productivity growth and relative price of nontradables

(OECD, 1970-85, percentage)

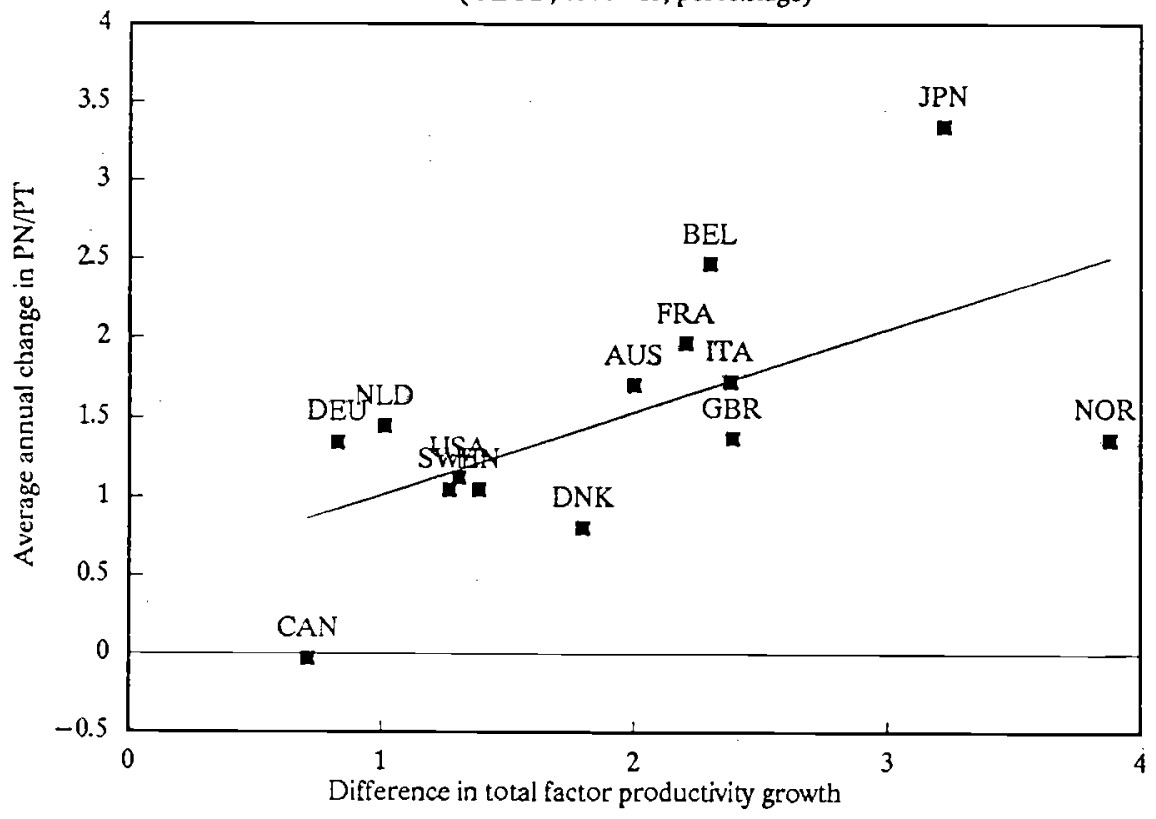

